\title{
A Historical Background of Plant Lighting: An Introduction to the Workshop
}

\author{
Raymond M. Wheeler \\ NASA Biological Sciences Office, Mail Code KT-B-1, Kennedy Space Center, FL 32899
}

Electric lamps have been used to grow plants for nearly 150 years with some of the earliest references being the work of Mangon (1861) and Prilleux (1869) (cited in Pfeiffer, 1926). As might be imagined, plant lighting technologies closely followed those used for human lighting, which took three general paths of development (Murdoch, 1985; Withrow and Withrow, 1947): 1) incandescent lighting, which was refined by Edison's invention of the incandescent filament lamp in 1879 ; 2) open arc lighting, which typically used carbon rods and became popular for street lighting in some cities in the late 1800s; and 3) enclosed gaseous discharge lamps, which were initially developed with mercury vapor in the late 1800 s (Murdoch, 1985).

Carbon arcs were probably the first lamps used to grow plants with an extensive study conducted by Siemens (1880) that even included an economic analysis on the use of electric lamps for commercial plant production-a concept he titled "ElectroHorticulture." Carbon arcs provided an intense point source with a broad, bluish spectrum and were still used for plant testing through the 1940s (Parker and Borthwick, 1949) but required regular replacement of the carbons and created hazards from their ultraviolet emission and exhaust products (Parker and Borthwick, 1949; Siemens, 1880).

In contrast to carbon arcs, incandescent filament lamps such as General Electric's "Mazda" lamps were simple and safe to operate and could last up to $3000 \mathrm{~h}$ if kept on continuously (Harvey, 1922). Because of this, Mazdas became the lamp of choice for controlled environment plant research in the 1920s and 1930s (Arthur and Harvill, 1937; Arthur and Stewart, 1935; Harvey, 1922; Pfeiffer, 1926). Mazdas and other incandescent lamps provided a redbiased light with a high amount of far-red and infrared radiation, which could generate heat and cause elongated stem growth (Arthur and Stewart, 1935). Nonetheless, incandescent lamps are still used in many plant growth chambers in combination with other lamps (e.g., Downs, 1977; Warrington et al., 1976).

The low-pressure discharge lamps using mercury vapor were tested in the late $1800 \mathrm{~s}$ and the concept was expanded circa 1900 to include other elements such as sodium, neon,

Received for publication 14 Mar. 2008. Accepted for publication 24 Apr. 2008. and argon (Murdoch, 1985). Plant growth and development under various types of lowpressure lamps were compared with that under the standard Mazda lamps by researchers at Boyce Thompson Institute and elsewhere in the 1930s, and these studies first revealed the potential of sodium lamps for plant lighting (Arthur and Stewart, 1935). Eventually the use of phosphors in conjunction with the low-pressure mercury lamps allowed development of fluorescent lamps in the 1930s, which provided a broader spectrum, improved electrical efficiency, and a longer operating life compared with incandescent lamps (Murdoch, 1985; Withrow and Withrow, 1947). Naylor and Gerner (1940) noted that D.R. Hoagland at the University of California and F.W. Went at Cal Tech, two icons in plant research, were some of the first to recognize the potential of fluorescent lamps for growing plants. As different phosphors became available, fluorescent lamp efficiencies continued to improve and even provided the ability to tailor the spectrum for plant growth and photobiological studies (Sager et al., 1982).

Further testing with gaseous discharge lighting led to the development of "high"pressure mercury lamps in the 1930s followed by metal halide and high-pressure sodium lamps in the 1950s and 60s (Murdoch, 1985). These high-pressure lamps had high electrical efficiencies, a long operating life, and provided a relatively broad spectrum light that was acceptable for a wide range of plant species (Cathey and Campbell, 1980). These lamps have become popular for use in growth chambers and currently are the lamps of choice for supplementing naturally lit greenhouses across much of the world.

All of the electric lighting principles noted so far were discovered and underwent initial development in mid- to late 1800 s with continued testing and refinement throughout the first half of the 1900s. With the possible exception of electrodeless lamps (Warmby, 1993), which are still largely untested for plant research and production (Both et al., 1997; Krizek et al., 1998), there have been few fundamental developments in plant lighting since the high-pressure, arc discharge lamps. This changed ca. 1990 with testing of light-emitting diodes (LEDs) for plant growth at the University of Wisconsin (Bula et al., 1991). Light-emitting diodes generate light through an electroluminescent principle (Craford et al., 2001) and thus are fundamentally different from other lamps used to date with plants. The rapid developments occurring in the manufacture and use of LEDs for traffic lights, automobile tail lights, billboards, and other applications (Craford et al., 2001) offer exciting opportunities for horticulture. The following papers summarize a series of talks presented at the 2007 ASHS workshop in Scottsdale, AZ. The workshop was entitled "LEDs in Horticulture," and the papers cover physical descriptions of the LEDs and engineering considerations for their use, a history of LED testing and development for plant applications, observations from some horticultural studies using LEDs, and the potential for using LEDs for fundamental photobiological research.

\section{Literature Cited}

Arthur, J.M. and E.K. Harvill. 1937. Plant growth under continuous illumination from sodium vapor lamps supplemented by mercury arc lamps. Contributions Boyce Thompson Inst. Plant Res. 8:433-443.

Arthur, J.M. and W.D. Stewart. 1935. Relative growth and dry weight production of plant tissue under Mazda, neon, sodium, and mercury vapor lamps. Contributions Boyce Thompson Inst. 7:119-130.

Both, A.J., L.D. Albright, C.A. Chou, and R.W. Langhans. 1997. A microwave powered light source for plant irradiation. Acta Hort. 418: 189-194.

Bula, R.J., R.C. Morrow, T.W. Tibbitts, D.J. Barta, R.W. Ignatius, and T.S. Martin. 1991. Lightemitting diodes as a radiation source for plants. HortScience 26:203-205.

Cathey, H.M. and L.E. Campbell. 1980. Light and lighting systems for horticultural plants. Hort. Rev. (Amer. Soc. Hort. Sci.) 2:491-537.

Craford, M.G., N. Holonyak, and F.A. Kish. 2001. In pursuit of the ultimate lamp. Sci. Am. 284: 63-67.

Downs, R.J. 1977. Incandescent lamp maintenance in plant growth chambers. HortScience 12: 330-332.

Harvey, R.B. 1922. Growth of plants in artificial light. Bot. Gaz. 74:447-451.

Krizek, D.T., R.M. Mirecki, S.J. Britz, W.G. Harris, and R.W. Thimijan. 1998. Spectral properties of microwave-powered sulfur lamps in comparison to sunlight and high-pressure sodium / metal halide lamps. Biotronics 27:6980.

Mangon, H. 1861. Production de la matière verte des feuilles sous l'influence de la lumière électrique. Compt. Rend. Acad. Sci. Paris. 53: 243-244. (cited in Pfeiffer, 1926).

Murdoch, J.B. 1985. Illuminating engineeringFrom Edison's lamp to the laser. Macmillan Pub. Comp., New York, NY.

Naylor, A.W. and G. Gerner. 1940. Fluorescent lamps as a source of light for growing plants. Bot. Gaz. 101:715-716. 
Parker, M.W. and H.A. Borthwick. 1949. Growth and composition of 'Biloxi' soybean grown in a controlled environment with radiation from different carbon-arc sources. Plant Physiol. 24:345-358.

Pfeiffer, N.E. 1926. Microchemical and morphological studies of effect of light on plants. Bot. Gaz. 81:173-195.

Prilleux, E. 1869. De l'influence de la lumière artificielle sur la réduction de l'acide carbonique par les plantes. Compt. Rend. Acad. Sci. Paris 69:408-412. (cited in Pfeiffer, 1926).

Sager, J.C., J.L. Edwards, and W.H. Klein. 1982. Light energy utilization efficiency for photosynthesis. Trans. ASAE 25:17371746.

Siemens, C.W. 1880. On the influence of electric light upon vegetation and on certain physical principles involved. Proc. Royal Soc. London 30:210-219.
Warmby, D.O. 1993. Electrodeless lamps for lighting: A review. IEE Proceedings-A 140:465-473.

Warrington, I.J., K.J. Mitchell, and G. Halligan. 1976. Comparisons of plant growth under four different lamp combinations and various temperature and irradiance levels. Agr. Meteorol 16:231-245.

Withrow, A.P. and R.B. Withrow. 1947. Plant growth with artificial sources of radiant energy. Plant Physiol. 22:494-513. 